\title{
Widokówka z Paryża. O polskich przekładach Madeline Ludwiga Bemelmansa
}

\section{Abstrakt:}

Artykuł dotyczy jedynych dotychczasowych przekładów Madeline (1939) Ludwiga Bemelmansa na język polski, które zostają zaprezentowane na tle rozważań o biografii i pozostałej twórczości pisarza. Tłumaczenia wykonane przez Zofię Kierszys (1998) i Małgorzatę Pietrzyk (2015) pozwalają polskiemu czytelnikowi zapoznać się z twórczością anglojęzycznego autora literatury dziecięcej. Autorka tekstu dowodzi, że różne strategie obrane przez dwie tłumaczki mogą wpływać na odbiór picturebooka, który w Polsce pojawił się prawie sześćdziesiąt lat po amerykańskiej premierze. Zestawiając ze sobą oryginał i polskie przekłady dzieła, ukazuje również na konkretnym przykładzie ewolucję norm tłumaczeniowych i tendencji translatorskich.

\section{Słowa kluczowe:}

literatura amerykańska, literatura dziecięca, Ludwig Bemelmans, Madeline, Małgorzata Pietrzyk, przekład, Zofia Kierszys

\section{A Postcard from Paris: On Polish Translations of Madeline by Ludwig Bemelmans}

\section{Abstract:}

The paper discusses the only translations of Ludwig Bemelmans's Madeline (1939) into Polish, which are presented against the background of the writer's biography and other works. Translations by Zofia Kierszys (1998) and Małgorzata Pietrzyk (2015) allow the Polish reader to become acquainted with the work of the English-language author of children's literature. The author of the paper proves how different strategies chosen by the two translators can affect the reception of the picture-

* Karolina Olech - mgr, przygotowuje rozprawę doktorską w Szkole Nauk o Języku i Literaturze, na Wydziale Filologii Polskiej i Klasycznej Uniwersytetu im. Adama Mickiewicza w Poznaniu dotyczącą recepcji przekładowej utworów Ludwiga Bemelmansa, Roalda Dahla oraz Sarah Crossan w Polsce. Kontakt: karolina.olech@amu.edu.pl. 
book which appeared in Poland almost sixty years after the American premiere. By juxtaposing the original work and the Polish translations, the author also shows the evolution of translation norms and trends on a concrete example.

Key Words:

American literature, children's literature, Ludwig Bemelmans, Madeline, Małgorzata Pietrzyk, translation, Zofia Kierszys

\section{Wprowadzenie}

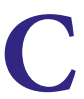
elem niniejszego artykułu jest analiza dwóch polskich przekładów $M a$ deline Ludwiga Bemelmansa (1939). Wychodząc od rozważań na temat sylwetki oraz biografii autora, chciałabym zapoznać polskiego czytelnika z dziejami tego mało znanego w Polsce utworu. Aby przybliżyć jedyne dotychczasowe tłumaczenia owego tekstu na nasz język, wykonane przez Zofię Kierszys i Małgorzatę Pietrzyk, przeprowadzam analizę porównawczą kilku wybranych fragmentów Madeline - szczególnie, moim zdaniem, istotnych dla dzieła Bemelmansa. Zestawienie oryginału z obiema polskimi wersjami tej opowieści pozwala ponadto na ukazanie pewnych tendencji $\mathrm{w}$ translatoryce literatury dziecięcej widocznych w wyborze dwóch różnych strategii przekładowych strategii, które obrazują, jak ewoluują normy tłumaczeniowe i tendencje translatorskie (Szymańska, 2014, s. 206). Takie podejście pozwala zaprezentować „[...] zarówno zyski, jak i straty istniejące w relacji tekst źródłowy - docelowy”, a także „[...] wskazać autonomię samych tłumaczeń” (Bilczewski, 2010, s. 286).

Zaproponowana przeze mnie analiza przekładów utworu Bemelmansa wpisuje się w żywotny i rozwijający się nurt badań poświęconych analizie przekładów literatury dziecięcej na język polski - by wspomnieć rozprawę Moniki Adamczyk-Garbowskiej (1988) poświęconą polskim tłumaczeniom angielskiej literatury dziecięcej ${ }^{1}$, monografię Ewy Rajewskiej (2004) dotyczącą przekładów dylogii Lewisa Carrolla $(1865,1871)$ o Alicji, publikacje Hanny Dymel-Trzebiatowskiej $(2013,2019)$ o tłumaczeniach utworów Astrid Lindgren i Tove Jansson, najnowszą książkę Aleksandry Wieczorkiewicz (2018) o przekładach Peter Pan in Kensington Gardens Jamesa Matthew Barriego (1906), a także liczne artykuły naukowe oraz publikacje monograficzne, które poruszają tę tematykę (m.in. Szymańska, 2009, 2010, 2014; dwa numery czaso-

Adamczyk-Garbowska (1990) jest także autorką wstępu do własnego tłumaczenia Winnie-the-Pooh. 
pisma Przekładaniec, zatytułowane Przekład literatury dziecięcej, 2006, i Baśń $w$ przekładzie, 2010). Te opracowania pokazują, jak wiele zmieniło się w podejściu do przekładu literatury dziecięcej na przestrzeni lat, co w szczególności wiąże się z odchodzeniem od tradycyjnej, starszej normy translatorskiej (udomowienia, które obok egzotyzacji wyróżnia Lawrence Venuti, 1998/2009, s. 240-241). Skutkiem tych przemian są - jak zauważa Izabela Szymańska (2014) - coraz częstsze "próby stosowania nowych norm w praktyce tłumaczeniowej" (s. 206).

\section{Ludwig Bemelmans, czyli kto?}

W 1898 roku w austriackim mieście Meran (obecnie Merano we Włoszech) urodził się Ludwig Bemelmans, autor znany światu nie tyle z powodu napisania wielu książek, choć ma ich w swoim dorobku niemało ${ }^{2}$, ile z wykreowania postaci rudowłosej dziewczynki o imieniu Madeline - postaci, w której już na zawsze pozostał pierwiastek samego twórcy.

Dzieciństwo pisarza było dalekie od wesołych przygód wspomnianej bohaterki. Gdy miał sześć lat, jego rodzice rozwiedli się, a w konsekwencji chłopiec, pozostający pod opieką ciężarnej matki, przeprowadził się do jej rodzinnego miasta - Ratyzbony. Po latach Bemelmans wyznał, że nienawidził niemieckiego stylu bycia i tamtejszej dyscypliny. Niemożność dopasowania się do otoczenia potęgowały liczne kompleksy chłopca - Ludwig był najmniejszym dzieckiem w klasie i czuł się wyobcowany, co mogło wynikać m.in. z faktu, że początkowo wychowywał się w innym kraju (Bemelmans Marciano, 1999, s. 5-6, 38). W okresie młodzieńczym powrócił do Austrii, aby tam odbyć staż w hotelu prowadzonym przez wuja. Doszło wówczas do incydentu, który znacząco zmienił bieg życia Bemelmansa. Jak wspominał sam autor w wywiadzie dla New York Timesa w 1941 roku:

Kierownik sali był podłym człowiekiem, a ja całkowicie mu podlegałem. [...] Chciał mnie sprać ciężkim skórzanym pasem, więc powiedziałem mu, że jeśli mnie uderzy, zastrzelę go. Uderzył mnie, a ja postrzeliłem go w brzuch. Przez chwilę wydawało się, że umrze. Ale nie umarł. Policja pouczyła jednak moją rodzinę, że wyślą mnie albo do poprawczaka, albo do Ameryki (Bromwich, 2018)³.

Napisał 18 książek dla dzieci i 22 dla dorosłych.

3 Jeśli nie podano inaczej, wszystkie tłumaczenia autorki artykułu - Karoliny Olech. Co ciekawe, wnuk pisarza w ogóle nie wspomina o tym zdarzeniu w biografii poświęconej dziadkowi (Bemelmans Marciano, 1999). 
Z tej przyczyny w 1914 roku Bemelmans udał się do Stanów Zjednoczonych ${ }^{4}$. Początkowo trudnił się pracą w restauracjach i hotelach, a następnie wstąpił do amerykańskiej armii. Niemieckie pochodzenie sprawiło jednak, że późniejszy twórca nigdy nie został wysłany na front. Postanowił więc zacząć pisać o tym, co znał najlepiej. I tak od lat 20. do połowy lat 30. XX wieku tworzył „[...] książki tylko dla dorosłych: beletrystykę, literaturę fantastyczną i literaturę faktu. [Poruszał] w nich głównie tematy, które były mu najbliższe: biznes hotelowy, podróże" (Zbierzchowska, 2018, s. 151).

Dopiero za namową May Massee, redaktorki działu książek dla dzieci wydawnictwa Viking Press, Bemelmans zaczął tworzyć dla najmłodszych (Bemelmans Marciano, 1999, s. 24). W dziełach dla niedorosłych odbiorców połączył talent pisarski z malarskim kunsztem, docenionym dopiero pod koniec życia ${ }^{5}$. Pierwszą książką stworzoną z myślą o dzieciach był nieprzetłumaczony do dziś na język polski Hansi (Bemelmans, 1934), „[...] nostalgiczna i malownicza opowieść" (Zbierzchowska, 2018, s. 151) o chłopcu, który z okazji Bożego Narodzenia odwiedza mieszkającego $\mathrm{w}$ górach wuja. Jednak to piąta ${ }^{6} \mathrm{w}$ dorobku Bemelmansa książka dla dzieci, wydana w 1939 roku Madeline, przyćmiła jego pozostałą twórczość i zapewniła mu sławę.

\section{Krótka historia Madeline (z Polską w tle)}

Gdyby nie interesujący splot zdarzeń, picturebook ${ }^{7}$ o przygodach Madeline zapewne nigdy by nie powstał. Sam Bemelmans w swoich szkicownikach zazna-

4 Jak pisze wnuk autora, Bemelmans przybył do Ameryki w wigilię Bożego Narodzenia, oczekując na spotkanie z ojcem, który jednak zapomniał odebrać nastoletniego syna z lotniska, przez co Ludwig spędził święta samotnie (Bemelmans Marciano, 1999, s. 10).

5 Jednym z miejsc, w których można podziwiać jego prace, są ściany baru w Hotelu Carlyle w Nowym Jorku. Bar nosi imię Bemelmansa, a na muralach przedstawiono epizody z książek o Madeline.

6 Po Hansim pisarz stworzył kolejno The Golden Basket (Bemelmans, 1936), w którym po raz pierwszy pojawiła się postać Madeline, The Castle Number Nine (Bemelmans, 1937) i Quito Express (Bemelmans, 1938).

7 Pojęcie picturebooka rozumiem i przyjmuję tu za Barbarą Bader (1976, s. 1). Zaproponowana przez nią definicja w przekładzie Małgorzaty Cackowskiej (2016) brzmi następująco: „[...] [książka obrazkowa (picturebook)] jest tekstem, ilustracjami i całościowym projektem; może być wykonana ręcznie albo stanowić komercyjny produkt; jest społecznym, kulturowym i historycznym dokumentem, a przede wszystkim jest doświadczeniem dla dziecka. Jako forma sztuki zależy od współbrzmienia obrazów i słów zaprojektowanych na rozkładówkach, w dramie przewracania kolejnych stron". 
czał, że do stworzenia książki o małej dziewczynce przebywającej w paryskiej szkole zainspirował go pobyt w szpitalu w Saint-Sauveur na Île d'Yeu, w którym znalazł się po tym, jak jedyny samochód na tej francuskiej wyspie potrącił go podczas przejażdżki rowerowej (Bemelmans Marciano, 1999, s. 36). W szpitalu, w sali obok, leżała dziewczynka po operacji wycięcia wyrostka robaczkowego, a nad łóżkiem Bemelmansa znajdował się pękający sufit, którego rysy kształtem przypominały królika - w książce taki sam strop był w pomieszczeniu, w którym przebywała po operacji Madeline ${ }^{8}$. Pisarz podkreślał również, że na charakter (i wygląd) tej bohaterki złożyły się cechy kilku osób. Mówił, że dziewczynka to mieszanka jego matki Frances (która opowiadała mu o szkole z internatem ${ }^{9}$ ), żony Madeleine zwanej „Mimi” (od której zapożyczył imię głównej bohaterki, zmieniając wszakże nieco zapis, aby móc łatwiej rymować), córki Barbary, a także niego samego, podobnie jak książkowa bohaterka - najmniejszego w klasie i wiecznie wpadającego w tarapaty (Bemelmans Marciano, 1999, s. 38).

Madeline zyskała ogromną popularność, choć warto zaznaczyć, że May Massee z Viking Press - która tak usilnie namawiała Bemelmansa do zajęcia się pisarstwem dla dzieci - po lekturze książki nie zdecydowała się na jej wydanie. Stwierdziła bowiem, że propozycja ta jest zbyt wyrafinowana dla najmłodszego odbiorcy. Opublikowaniem tekstu zajęło się wydawnictwo Simon \& Schuster, które natychmiast wypuściło Madeline na rynek, a książka szybko stała się bestsellerem (Bemelmans Marciano, 1999, s. 40). Mimo niebywałego sukcesu autor potrzebował ponad dziesięciu lat, aby napisać kolejną część przygód rezolutnej dziewczynki, Madeline's Rescue [Na ratunek Madeline] (Bemelmans, 1953), nagrodzoną w 1954 roku Medalem Caldecotta - wyróżnieniem przyznawanym ilustratorowi najlepszego amerykańskiego picturebooka wydanego w roku poprzedzającym przyznanie nagrody. Do roku 1961 powstały jeszcze cztery części serii: Madeline’s Christmas [Gwiazdka Madeline] (Bemelmans, 1956/1985; tom ten ukazał się pierwotnie w świątecznej edycji czasopisma McCall's, a jako oddzielna książka wydany został już po śmierci pisarza), Madeline and the Bad Hat [Madeline i gagatek] (Bemelmans, 1956),

8 W oryginale: „[...] a crack in the ceiling had the habit / of sometimes looking like a rabbit” (Bemelmans, 1939, s. [33]), w przekładzie Zofii Kierszys: „I rysy na suficie / wnet się okazały / królikiem - czy wierzycie? - / długouchym, białym” (Bemelmans, 1939/1998b, s. [29]), w przekładzie Małgorzaty Pietrzyk: „Czasem na suficie rysa / przybierała kształt królika” (Bemelmans, 1939/2015a, s. 39).

9 Czyli o tzw. convent school, „prowadzonej przez siostry zakonne w Altötting” (Bemelmans, 1985/2015c, s. 317), w której łóżka znajdowały się w dwóch równych rzędach, a dziewczynki chodziły w takich samych strojach. 
Madeline and the Gypsies [Madeline i Cyganie] (Bemelmans, 1959) oraz Madeline in London [Madeline w Londynie] (Bemelmans, 1961) ${ }^{10}$. Ciekawym faktem jest też korespondencja Bemelmansa $\mathrm{z}$ Jacqueline Kennedy $-\mathrm{z}$ amerykańską pierwszą damą chciał podjąć współpracę nad kolejną częścią przygód Madeline. Tom miał nosić tytuł Madeline Visits Caroline. Śmierć autora w 1962 roku pokrzyżowała jednak te plany. Dzieło przejął i dokończył wnuk pisarza, John Bemelmans Marciano, który skompilował zbiór pt. Madeline in America and Other Holiday Tales (2011), a później przygotował kilka własnych książek poświęconych perypetiom Madeline, wiernie oddając oryginalny sposób tworzenia tekstu oraz ilustracji ${ }^{11}$.

W Polsce Madeline pojawiła się dopiero w 1998 roku za sprawą przekładu Zofii Kierszys. Wybitna tłumaczka wielu amerykańskich i angielskich tekstów literackich - posiadająca w swoim dorobku przekłady dzieł Williama Faulknera i Harper Lee, tłumacząca także poezję dla dzieci Milne’a ${ }^{12}$ - przełożyła dwa z sześciu utworów Bemelmansa wchodzących w skład oryginalnego cyklu, dzięki czemu do rąk polskiego odbiorcy trafiły Madeline (Bemelmans, 1939/1998b) oraz Gwiazdka Madeline (Bemelmans, 1956/1998a). Książki w przekładzie Kierszys nie zyskały jednak rozgłosu. Postać małej wychowanki paryskiej szkoły z internatem stała się popularna raczej za sprawą animowanego serialu telewizyjnego emitowanego w latach 90. XX wieku oraz na początku XXI wieku, luźno opartego na twórczości Bemelmansa (Heyward, Maliani, London, Cooper, Kohner, 1993, 1995-2001). Najnowszy i, jak do tej pory, ostatni przekład - autorstwa Małgorzaty Pietrzyk, znanej m.in. z tłumaczenia książek dla dzieci autorstwa Benjiego Daviesa - już na okładce odwołuje się do popularności tej kreskówki ${ }^{13}$. Wspomniana wyżej tłumaczka ponadto jako jedyna przełożyła na język polski wszystkie klasyczne książki o Madeline. Tom zatytułowany Madeline w Pary-

10 Przekłady tytułów w nawiasach kwadratowych podano za tłumaczeniem Małgorzaty Pietrzyk.

11 W dorobku wnuka twórcy znajdują się następujące pozycje poświęcone przygodom Madeline: Madeline Says Merci (Bemelmans Marciano, 2001), Madeline Loves Animals (Bemelmans Marciano, 2005), Madeline and the Cats of Rome (Bemelmans Marciano, 2008), Madeline at the White House (Bemelmans Marciano, 2011) oraz Madeline and the Old House in Paris (Bemelmans Marciano, 2013). Nieprzetłumaczona pozostaje również przywoływana tutaj biografia autora napisana przez Bemelmansa Marciano (1999), a zatytułowana Bemelmans: The Life and Art of Madeline's Creator.

12 O dorobku przekładowym Kierszys pisała Ewa Rajewska (2015) w tekście Twórczość przekładowa kobiet.

13 Hasło „Niezapomniana Dobranocka” (Bemelmans, 1939-1961/2015b, pierwsza strona okładki) zostało wyeksponowane - zapewne w celu marketingowym - i w pewnej mierze wyparło nawet nazwisko autora, znajdujące się u dołu okładki. 
$\dot{z} u$ (Bemelmans, 1939-1951/2015b) jest przekładem zbioru A Madeline Treasury (Bemelmans, 1939-1951/2014) zawierającego sześć opowiadań ${ }^{14}$. W polskiej historii przekładowej na razie próżno szukać tłumaczeń tekstów napisanych przez wnuka autora - Johna Bemelmansa Marciano.

\section{Dwie tłumaczki, dwie strategie. Analiza przekładów Madeline na język polski}

Wierszowane historie o małej dziewczynce, w których słowo dopełniane jest przez ilustracje przypominające dziecięce rysunki (dość schematyczne, ale obfitujące w szczegóły), stawiają przed tłumaczem wiele wyzwań. Rymowany, rytmiczny i zwarty tekst, pisany przez Bemelmansa dość krótką frazą, nie jest charakterystyczny dla polskiej literatury dziecięcej, która sięga zwykle po dłuższe wersy. Także rymy męskie, tak częste $\mathrm{w}$ oryginale, $\mathrm{w}$ polskiej poezji są rzadkością. Kolejnym problemem dla tłumacza mogą być stosowane przez autora współbrzmienia i gry lingwistyczne. Bemelmans w swoich tekstach bawi się językiem, jego dźwięcznością, melodią i rytmem. To w tym upatrywałabym dominanty semantycznej (Barańczak, 1990/1992a, s. 36-37) ${ }^{15}$ opowieści o Madeline - w szczególnym smakowaniu języka, w radości układania słów, które współbrzmią, dźwięczą, mnożą aliteracje, onomatopeje.

Krótkie zdania oznajmujące oraz rymy Bemelmansa wkradają się do języka czytelników, stają się elementami kodu, który sprzyja zapamiętywaniu całych wersów. Lekkość, przypominająca niekiedy frazę Juliana Tuwima z jego wierszy dla dzieci, sprawia, że kolejne pokolenia anglojęzycznych czytelników cytują Madeline z pamięci. Owa swoista "naturalność” jest najistotniejszym elementem kolejnych utworów wchodzących w skład omawianej serii ${ }^{16}$. Opo-

14 Jest to wznowienie książki Mad about Madeline: The Complete Tales (Bemelmans, 1939-1961/2001). Warto dodać, że Madeline w Paryżu została wpisana na listę książek polecanych przez Fundację „ABCXXI - Cała Polska czyta dzieciom” (2019) do czytania najmłodszym odbiorcom (od szóstego roku życia).

15 Jak pisze Stanisław Barańczak (1990/1992a): „[...] mówmy najostrożniej o semantycznej dominancie, prymacie określonego elementu struktury utworu, który stanowi mniej lub bardziej dostrzegalny klucz do całokształtu jego sensów. Dostrzec ten klucz i zrobić z niego odpowiedni użytek - to zadanie zarówno dla czytelnika, jak dla krytyka-interpretatora, jak i wreszcie dla tłumacza utworu" (s. 36-37).

16 Potwierdzeniem tych słów jest Wstęp autorstwa Anny Quindlen (2001/2015) do łącznego wydania przygód małej bohaterki: „[...] Madeline była traktowana w naszej rodzinie nie jak książka, a raczej jak język i podejście do życia [...]. Mogę recytować Madeline z pamięci, o czym moje dzieci dobrze wiedzą. Ale prawdopodobnie i one mogą cytować fragmenty" (s. 9). 
wieść płynie wartko i rytmicznie, dźwięcząc w kolejnych współbrzmieniach, a pewne zaburzenia i dysonanse podkreślają tylko jej „autentyczność”. Przerzutnie, stosowane przez Bemelmansa (1939) w miejscach, w których chciał on zachować rym, niekiedy zaburzają wszakże płynność czytania:

And soon after Dr. Cohn

came, he rushed out to the phone

[...]

Madeline woke up two hours

later, in a room with flowers.

$\overline{[\ldots]}$

and she said, „Please children do-

tell me what is troubling you [wyróżnienia własne]?” (s. [27, 31, 50]).

Z tego faktu zdawały sobie sprawę autorki obu polskich przekładów, które starały się odtworzyć specyfikę języka Bemelmansa - łączącego błyskotliwość i prostotę, mnożącego implikowane sensy w bezpośrednim przekazie. Każda z nich zrobiła to na swój sposób, zależny m.in. od tendencji dominujących w przekładach literatury dziecięcej w momencie tworzenia każdego $\mathrm{z}$ tłumaczeń.

Kierszys przystosowała tekst do polskich realiów, w przekładzie postawiła na rytm i rym. Pietrzyk postarała się natomiast zachować zagraniczny kontekst kulturowy, a także trzymać się litery oryginału. Jednocześnie przekład z 1998 roku momentami jest bliski parafrazie, stosowane jest w nim udomowienie, a także, co istotne, pogwałcony zostaje w tym tłumaczeniu szczególny - typowy dla picturebooków - pakt dotyczący równowagi między tekstem a ilustracją. Kierszys nie wierzy w możliwości interpretacyjne odbiorcy: pozostawia czytelnikom niewielkie pole dla wyobraźni, pragnie wszystko uszczegółowić, dopowiedzieć i skomentować. Utwory Bemelmansa w wersji Pietrzyk są z kolei bardziej zwarte, bliższe sensom pierwowzoru, oddające nastrój Paryża z pierwszej połowy ubiegłego stulecia. Odmienność tych tekstów jest przejawem i skutkiem szerszych przemian w poezji dla dzieci (również w przekładach poetyckich). Możemy w omawianych przykładach zaobserwować przejście od poezji opisowej (szeroko komentującej wydarzenia ukazane w rozległym kontekście, z troską o skuteczność przekazu kierującej uwagę odbiorcy ku istotnym szczegółom ilustracji) do poezji bardziej skondensowanej (niestroniącej od chwytów właściwych twórczości awangardowej czy lingwistycznej). W przekładzie Kierszys dorosły nadawca opowiada hipotetycznemu dziecięcemu odbiorcy o przygodach Madeline. W tłumaczeniu Pietrzyk dziecko może być aktywnym uczestnikiem procesu lektury, może dokonywać zindywidualizowanych 
konkretyzacji, śledzić powiązania między tekstem i ilustracjami, empatycznie wejść $\mathrm{w}$ świat przedstawiony i utożsamić się z jedną z dwunastu dziewczynek.

Oryginalny tekst Madeline na pierwszy rzut oka wydaje się bardzo prosty (jest bowiem krótki) i sprawia wrażenie, że tłumaczenie go na język obcy będzie zadaniem łatwym i przyjemnym. Nic bardziej mylnego. Bemelmans to pisarz o skomplikowanej, niekoherentnej tożsamości - i z tej przyczyny nie był zakorzeniony w żadnym języku. Jego znajomość angielszczyzny była szczególna. Styl Madeline jest lekki, zrytmizowany, jednak momentami widać, że nie jest to ojczysty język autora. Bemelmans niejako dostosowywał język do siebie ${ }^{17}$, a to wpłynęło na sposób, w jaki pisał, oraz na poetykę jego dzieła - głównych cech owej twórczości można upatrywać w nieregularnych wersach, zaburzonych rymach, kupletach przemieszanych z tripletami. $Z$ tego powodu tłumaczenie tekstu z zachowaniem właściwego mu rytmu nie jest łatwe. Mierzyć się z tym zadaniem próbuje Kierszys, która - aby zachować rytm - czasem oddala się od oryginału, a dodatkowo stosuje strategię udomawiającą. I tak oto w zdaniu rozpoczynającym omawianą opowieść (a także każdą z pozostałych części serii) czytamy:

In an old house in Paris

that was covered with vines

lived twelve little girls in two straight lines (Bemelmans, 1939, s. [9-10]).

W przekładzie Kierszys pojawia się znacząca amplifikacja:

W Paryżu w kamieniczce oplecionej wszędzie

jak na wsi dzikim winem [wyróżnienie własne]

mieszkało po sześć w rzędzie

dwanaście dziewczynek (Bemelmans, 1939/1998b, s. [5-6]).

Trzeba wszakże przyznać, że od subtelnej amplifikacji nie odeszła i Pietrzyk:

W Paryżu, w pewnym starym domu, który był porośnięty dzikim winem, ustawiało się co rano [wyróżnienie własne] w dwa rzędy dwanaście małych dziewczynek (Bemelmans, 1939/2015a, s. 15-16).

17 W wywiadzie wspomina o tym także wnuk autora: „Marciano opowiadał o pochodzeniu niektórych specyficznych rymów Madeline. Jak wyjaśnia, jego dziadek: »Nie mówił w żadnym języku bez akcentu. Nie wiem, czy tak naprawdę w ogóle miał rodzimy język. Mówił po francusku, dopóki nie ukończył pięciu lat, następnie przeprowadził się do Niemiec i używał niemieckiego do trzynastego albo czternastego roku życia. Kiedy skończył osiemnaście lat, przeniósł się do Ameryki. Myślę, że miał wtedy te wszystkie języki w pamięci«" (Kellog, 2013). 
W przekładzie Pietrzyk taki dodatek zmienia w tekście niewiele, jest potrzebny do zachowania rymu. Fragment w tłumaczeniu Kierszys różni się od pierwowzoru już bardziej, ponieważ inaczej zaczyna wyglądać obrazowane miasto Paryż staje się sielski, przyjemnie wiejski. Wydaje się to dalekie od oryginału. W pierwowzorze bowiem dziewczynki przebywają najczęściej w centrum francuskiej stolicy - po Paryżu wszędzie chodzą pieszo.

Niekiedy zdarza się, że Kierszys zamiast tekstu tłumaczy ilustracje. We fragmencie opowiadającym o przechadzce dziewczynek w oryginale czytamy:

They smiled at the good and frowned at the bad and sometimes they were very sad (Bemelmans, 1939, s. [14-16]).

Kierszys proponuje następujący przekład tych wersetów:

Uśmiechały się widząc życzliwość dla zwierząt, wykrzywiały się brzydząc paskudną kradzieżą i współczuły serdecznie kalekim żołnierzom (Bemelmans, 1939/1998b, s. [10-12]).

Wymienione przez tłumaczkę czynności rzeczywiście można dostrzec na ilustracjach towarzyszących tekstowi: widzimy na nich mężczyznę karmiącego konia („uśmiechały się widząc / życzliwość dla zwierząt”), żandarma, który ściga złodzieja („wykrzywiały się brzydząc / paskudną kradzieżą”), czy rannego żołnierza przed Pałacem Inwalidów („i współczuły serdecznie / kalekim żołnierzom”). Taki zabieg jest charakterystyczny dla Kierszys, która w przekładzie, jak już wspomniałam, wykorzystuje udomowienie jako naczelną strategię translatorską. Warto zauważyć, że tak rozbudowana fraza wydłuża opowieść, co może po części zaburzyć płynną i szybką lekturę połączoną z zainteresowaniem ilustracją.

Co ciekawe, Kierszys - odchodząc od oryginału na rzecz budowania treści, które odbiorca może w prosty sposób przyswoić - nagina tekst do ilustracji, aby w ten sposób uzyskać pełniejsze połączenie elementów werbalnych i wizualnych. Takie podejście bliskie jest temu, o czym w swoich pracach naukowych pisze Riitta Oittinen. Według tej autorki, jak tłumaczy Michał Borodo (2006), „nieskrępowany oryginałem tłumacz ma [...] prawo do subiektywnych interpretacji i adaptacji, które na nowo ożywiają tekst dla dziecka" (s. 16). Oittinen (2000) w swojej książce Translating for Children niejako przenosi zainteresowanie $\mathrm{z}$ oryginału na przekład i jego twórcę. Wiąże się to z faktem, że kluczowe 
staje się dla niej tłumaczenie na potrzeby głośnego czytania oraz korelacja przekładanego tekstu z ilustracjami (Borodo, 2006, s. 16). Kierszys robi w zasadzie to, co zaleca przywołana badaczka - ułatwia dziecięcemu odbiorcy zadanie, niejako interpretując oryginał specjalnie dla niego. Warto w tym miejscu wspomnieć o stanowisku Stanisława Barańczaka (1975/1992b) wobec tłumaczenia poezji dla dzieci - autor uważał, że jest ono przekładem nie wtórnym, lecz samoistnym, pierwotnym (s. 67). Także nadorganizacja językowa - bez której potrafi się obyć poezja dla dorosłych ${ }^{18}-\mathrm{w}$ poezji dla dzieci jest czymś niezbędnym i niejako pożądanym (s. 69). To podejście jest także widoczne w praktyce translatorskiej Kierszys. Wykorzystywanie brzmienia słów oraz zachowywanie rymów i rytmu, nierzadko kosztem tekstu oryginału, to znaki rozpoznawcze jej przekładu.

Inną drogę obiera Pietrzyk, która trzymając się litery pierwowzoru, proponuje następującą wersję omawianego fragmentu tekstu:

Dobro witały z uśmiechem,

na widok zła marszczyły brew,

a czasem wielki smutek

przenikał do ich serc (Bemelmans, 1939/2015a, s. 20-22).

Tłumaczka nie interpretuje i nie eksplicytuje ilustracji. Stara się zachować dystans wobec przekazywanych w tekście treści - tak jak oryginał. Pietrzyk, dbając o bliską relację języka przekładu z językiem oryginału, nie zawsze radzi sobie natomiast z poetyckością tekstu. Jej rymy są często niepełne lub gramatyczne, co zaburza charakterystyczną dla Bemelmansa lekkość oraz płynność towarzyszącą lekturze pierwowzoru. Przytoczony wyżej fragment - mówiący między wierszami o trudnych i ważnych sprawach, takich jak zło, wojna - w przekładach znakomicie odkrywa odmienne strategie tłumaczek. Kierszys kieruje się bardziej czynnościami, zachowaniami, aby pokazać, co jest dobre, a co złe. Pietrzyk do tego celu wykorzystuje pojęcia abstrakcyjne - „dobro”, „zło", tym samym wprowadzając metapoziom do tekstu.

W opisie codziennego dnia dziewcząt pojawia się również (powtarzana na początku i końcu opowieści) fraza:

In two straight lines they broke their bread and brushed their teeth and went to bed (Bemelmans, 1939, s. [11-13]).

18 Wystarczy wspomnieć tutaj karierę wiersza białego i wolnego. 
Najbardziej interesuje mnie tutaj związek to break bread. Jest on o tyle ciekawy, że posiada znaczenie zarówno symboliczne, jak i idiomatyczne. Owo „dzielenie się chlebem”, „łamanie chleba” nie tylko stanowi zwyczajną czynność, lecz także jest pewną interakcją społeczną, spotkaniem we wspólnocie (FirstMan, 2010). W przekładzie Kierszys to znaczenie zanika, a na pierwszy plan - po raz kolejny - zostaje wysunięty rym:

Zawsze dwa proste rzędy:

przy stole w jadalni

i kiedy myły zęby

i spały w sypialni (Bemelmans, 1939/1998b, s. [7-9]).

Z kolei Pietrzyk kładzie większy nacisk na przywołane wyżej znaczenie związku to break bread, choć fragment w jej przekładzie nie jest bliski aliteracyjnej frazie oryginału:

Dziewczynki w dwóch równych rzędach

dzieliły każdą kromkę i okruszek,

myły zęby

i kładły się spać do łóżek (Bemelmans, 1939/2015a, s. 17-19).

Dodatkowo, we fragmencie w przekładzie Pietrzyk zaburzony zostaje obraz szkoły z internatem, w której przebywają dziewczęta, ponieważ dzielenie się „każdą kromką i okruszkiem” konotuje ogromną biedę, a przez to szkoła w czytelniczej wyobraźni może przybrać formę sierocińca.

Kolejnym problemem, którego przysparza tekst oryginału, jest imię głównej bohaterki. Obie tłumaczki zachowują oryginalną pisownię, jednak nigdzie nie pojawia się informacja, jak należałoby to imię odczytywać. Czy z francuska [madə'len], czy może jednak, jak w przypadku pierowzoru, ['mædəlaın] ${ }^{19}$ ? Jest to kwestia, która podczas głośnej lektury - a raczej taka towarzyszy czytaniu picturebooka - sprawia wiele kłopotów. Podobny problem wiąże się z postacią panny $\mathrm{Clavel}^{20}$. Pietrzyk unika udomowienia, zachowuje oryginalną pisownię,

19 Oryginał, poprzez użycie imienia Madeline w pozycji rymowej, narzuca wymowę ['mædəlain]: „In rain / or shine - the smallest one was Madeline” (Bemelmans, 1939, s. [18-20]). W przekładach imię nie pojawia się w pozycji rymowej, przez co nie można mówić o pożądanej wymowie. Co ciekawe, we wspomnianym wcześniej serialu animowanym imię głównej bohaterki w polskim dubbingu jest wymawiane jako [madə'len], a w oryginale - jako ['mædəlain].

20 Postać panny Clavel jest interesująca również z powodu jej tożsamości, chciałoby się rzec - zawodowej. Mianowicie w anglojęzycznym nieprofesjonalnym dyskursie pojawia się 
nie zmieniając nazwiska bohaterki. Kierszys z panny Clavel czyni zaś pannę Rozsądek. Zabieg ten sprawia, że tekst traci na swojej (pociągającej) obcości. Pierwsza z tłumaczek nie ucieka również od wyrażeń potocznych. Kiedy do dziewcząt przybywa lekarz, aby stwierdzić, co dolega Madeline, w oryginale diagnozuje: „Nurse, [...] it's an appendix!” (Bemelmans, 1939, s. [28]). Appendix to nic innego jak (w tym przypadku) krótsza forma od vermiform appendix, czyli wyrostka robaczkowego. Jednak u Kierszys zamiast wyrostka pojawia się „ślepa kiszka” (Bemelmans, 1939/1998b, s. [24]). To potoczne wyrażenie dziś może być już nieczytelne dla najmłodszego odbiorcy. Dodatkowo, tłumaczka po raz kolejny na plan pierwszy wysuwa polski kontekst - tym samym akcja zostaje osadzona w quasi-polskich realiach, a przez to oddala się od biograficznego śladu historii snutej przez Bemelmansa (obserwowanie dziewczynki we francuskiej szpitalnej sali).

W tym miejscu chciałabym zwrócić uwagę na jeszcze jeden element, który bezpośrednio nie dotyczy różnic widocznych w strategiach tłumaczek, ale wpływa na recepcję przekładów, która również jest istotna. Mam tutaj na myśli starzenie się języka docelowego. Kierszys była niemal osiemdziesięciolatką, gdy pracowała nad przekładem Madeline (książka została wydana pod sam koniec życia tłumaczki), i miała zupełnie inny bagaż językowy niż Pietrzyk. Jest to niezwykle ważny kontekst, który uświadamia, że idiolekty tłumaczek kształtowały się w odmiennych realiach. Sam język, którym posłużyła się Kierszys, w momencie wydania przekładu był już jakby z innej epoki, nieco archaiczny. Choć oba tłumaczenia dzieli zaledwie siedemnaście lat, to doskonale widać, że pewne sformułowania zestarzały się i mogą być już niejasne (wspomniana „ślepa kiszka” czy „niebożątko”, przywodzące na myśl utwory Marii Konopnickiej i Marii Kownackiej), choć bez wątpienia przemawiają do dziecięcej wyobraźni ${ }^{21}$.

wątpliwość, czy panna Clavel była zakonnicą, czy też nie. Sam Bemelmans mówił, że Clavel jest nauczycielką, a nie zakonnicą, co wiąże się z tym, że old house jest szkołą z internatem, a nie sierocińcem (b.a., b.d.b). Spór jednak trwa, a na różnych stronach internetowych poświęconych Madeline można przeczytać, że Clavel zapewne jest zakonnicą, do której dziewczęta zwracają się Miss (franc. Madame), ponieważ tak zwracały się do siebie zakonnice ze Zgromadzenia Najświętszego Serca Jezusa założonego przez św. Magdalenę Zofię Barat. Prowadziły one szkoły, na których szkoła Madeline wydaje się wzorowana (b.a., b.d.a).

${ }^{21}$ Choć nie jest to przedmiotem niniejszej analizy, warto zwrócić uwagę na fakt, że Pietrzyk w kolejnych częściach przygód Madeline także korzysta z udomowień (pies Genowefa - Genevieve), używa nieco osobliwych słów, takich jak „gagatek” (określenie, którym posługuje się, opisując psotnika Pepito), i stosuje niekoniecznie znane przez małych odbiorców słowa, np. we fragmencie: „To nie są żadne fanaberie, / przyjdźcie zobaczyć mą menażerię” (Bemelmans, 1939/2015a, s. 133). 
Innym ciekawym fragmentem obu przekładów jest epizod związany z przybyciem doktora Cohna do domu pacjentki. Kierszys pomija nazwisko lekarza, a Pietrzyk, zapewne aby ułatwić wymowę, decyduje się zmienić je na Kohn, co jednak wprowadza nowy, zbędny kontekst (nazwisko Cohn wygląda bardziej angielsko, a Kohn - niemiecko). Po zbadaniu Madeline lekarz poszukuje telefonu, aby zadzwonić do szpitala:

And soon after Dr. Cohn

came, he rushed out to the phone

and he dialed: DANton-ten-six-

„Nurse”, he said, „it's an appendix!” (Bemelmans, 1939, s. [27-28]).

Fragment ten w obu przekładach, kolejno Kierszys i Pietrzyk, wygląda następująco:

Pan doktor przyszedł prędko

i wykrzyknął on:

„Niedobrze z tą pacjentką!

Gdzie tu jest tele-FON?!"

Gdy przeszła mu zadyszka,

już normalnym głosem

rzekł:

„Siostro, ślepa kiszka.

O karetkę proszę" (Bemelmans, 1939/1998b, s. [23-24]).

Ledwie ją zbadał doktor Kohn,

od razu - łaps za telefon.

Wykręcił numer alarmowy:

- Siostro, wyrostek robaczkowy! (Bemelmans, 1939/2015a, s. 33-34)

Bardzo długi fragment w przekładzie Kierszys stanowi raczej swobodną interpretację utworu oryginalnego. Chciałabym jednak zająć się innym elementem tekstu przysparzającym tłumaczkom wielu problemów, a mianowicie kwestią numeru telefonu, który wybiera doktor. Jest to dziwny numer, który - jak się okazuje - służy Bemelmansowi tylko do zrymowania z wyrostkiem (Ferris, 2018). Kierszys proponuje zapis słowa „tele-FON”, rymując go gramatycznie z „on” (Bemelmans, 1939/1998b, s. [23]). Zastosowana przez tę tłumaczkę transakcentacja sprawia, że fragment w przekładzie jest zabawny, humorystyczny, a w dodatku imituje francuski, oksytoniczny akcent na ostatnią sylabę. Swoboda oraz adaptacja w praktyce translatorskiej pozwalają na więcej humoru - i tak dzieje się w tłumaczeniu Kierszys. Zaproponowane 
przez Pietrzyk rozwiązanie pomija ten aspekt tekstu: autorka przekładu wprowadza „numer alarmowy” (Bemelmans, 1939/2015a, s. 34), który narzuca konotacje związane $\mathrm{z}$ numerem pogotowia. Po przewiezieniu do szpitala i operacji Madeline spędza na rekonwalescencji dziesięć dni, a dowiadujemy się tego $\mathrm{z}$ fragmentu:

Outside were birds, trees, and sky and so ten days passed quickly by (Bemelmans, 1939, s. [34]).

Krótki, rymowany dwuwiersz zostaje w tłumaczeniu Kierszys rozbudowany pojawiają się tutaj amplifikacje, a dokładniej ukonkretnienia:

Za oknem na kasztanie śpiewał chyba szczygieł.

Dziesięć dni z tym śpiewaniem [wyróżnienia własne] przeleciało migiem (Bemelmans, 1939/1998b, s. [30]).

Pietrzyk w tłumaczeniu tego samego fragmentu unika amplifikacji, stosuje jednak rymy niedokładne i współbrzmienia niekiedy bardzo odległe od siebie:

Za oknem śpiewały ptaki, rosło drzewo -

dziesięć dni raz-dwa minęło (Bemelmans, 1939/2015a, s. 40).

W swoim przekładzie Kierszys, jako że bardzo często obiera strategię udomowienia, rozbija rytm, choć zachowuje rymy - jednak są to rymy, które odpowiadają własnej inwencji tłumaczki, niekoniecznie zaś tekstowi oryginału. W pierwowzorze Bemelmans (1939) pisze:

in they walked and then said, „Ahhh,”

when they saw the toys and candy

and the dollhouse from Papa (s. [40]).

W przekładzie Kierszys czytamy zaś:

Ojejku! Niespodzianka,

istny raj zabawek!

Prezentów od rodziny

jak na imieniny.

Dom dla lalek, skakanka, ciastka, korba nawet [wyróżnienia własne]! (Bemelmans, 1939/1998b, s. [36]) 
W tym fragmencie widać, jak bardzo tłumaczka podąża za ilustracją, a nie oryginałem. Nie dość, że brak wzmianki o Papie (wprowadzona do tekstu Bemelmansa figura ojca zrywa z myśleniem o szkole, w której przebywają dziewczęta, jako sierocińcu), to jeszcze „korba” wymieniana jako jeden $z$ prezentów, a pojawiająca się w tekście wcześniej jako element szpitalnego łóżka („On her bed there was a crank" - Bemelmans, 1939, s. [32]), zaburza logikę tekstu. Omawiany fragment przekładu jest także zdecydowanie bardziej zabarwiony emocjonalnie niż oryginał - składa się z wykrzyknień, podczas gdy w pierwowzorze mamy oznajmienia, a przy tym narrator (tłumaczka?), jest tym, kto wypowiada zdania; jest narratorem (tłumaczką?) zaangażowanym, emocjonalnym, co widać także w innym miejscu przekładu: „I rysy na suficie / wnet się okazały / królikiem - czy wierzycie? [wyróżnienie własne] - / długouchym, białym” (Bemelmans, 1939/1998b, s. [29]). W tłumaczeniu Kierszys rym całkowicie panuje nad wersem, czego skutkiem są pojawiające się w tłumaczeniu nowe elementy (raj zabawek, skakanka). Warto jednak w tym miejscu zaznaczyć, że w przekładzie z języka angielskiego na polski trudno zachować rytm i rym ze względu na specyfikę obu systemów językowych - w polszczyźnie słowa są najczęściej dłuższe niż w angielszczyźnie, przez co frazy w przekładzie się wydłużają, ośmiozgłoskowiec zastępuje się często jedenastozgłoskowcem, rzadko udaje się zachować takie same rymy, a polski stały akcent paroksytoniczny nie ułatwia tłumaczowi zadania.

Moje uwagi nie stanowią próby stworzenia wartościującej hierarchii dwóch dostępnych przekładów utworu Bemelmansa na język polski, a powyższe analizy porównawcze wybranych fragmentów dają tylko częściowe pojęcie o zadaniach, które przed tłumaczami stawia seria o przygodach Madeline. Twórczość tego autora wymaga pewnej językowej swobody, umiejętności bawienia się słowem, a zarazem jednak - pozostania w bliskości z myślami i słowami pisarza. Wyzwania w przekładzie Madeline polegają bowiem na tym, aby, po pierwsze, nie „przegadać” opowieści (nie przyćmić jej sensu przez użycie zbyt wielu słów), która wraz z ilustracjami dopowiadającymi to, czego w tekście brak, tworzy spójne dzieło, a po drugie, by zachować rytm i rym, tak ważne dla samego Bemelmansa i dla głośnej lektury jego tekstów, przy jednoczesnym utrzymaniu obcego kontekstu kulturowego. Dla pisarza, miłośnika Francji i Paryża, ów kontekst był niezwykle ważny i nieustannie pojawia się w jego twórczości ${ }^{22}$.

$22 \mathrm{Na}$ ilustracjach do książki znajduje się wiele paryskich obiektów ważnych dla Francuzów, m.in. wieża Eiffla, pałac Inwalidów, katedra Notre Dame, Luwr czy bazylika Sacré-Cœur. 
Obie polskie tłumaczki Bemelmansa starają się na swój sposób sprostać tym wymaganiom i obierają dwie zupełnie różne strategie, dwa podejścia do przekładu literatury dziecięcej. Tłumaczenie Kierszys, kierującej się potrzebami dziecięcego czytelnika i specjalnie dla niego udomawiającej historię Madeline, jest bliskie strategii adaptacyjnej, która szczególnie popularna była $\mathrm{w}$ pierwszej połowie XX wieku. Zmieniając tekst, przystosowując go do polskich realiów, Kierszys bardzo dobrze radzi sobie z rymami, choć w jej tłumaczeniu pojawia się wspomniane wyżej „przegadanie” tekstu. Pietrzyk, trzymająca się znacznie bliżej oryginału i jego wykładni, sprawia zaś, że przekład nie zaburza konwencji picturebooka, nie infantylizuje go. Jest to strategia bliższa tej proponowanej przez Göte Klingberga (1986), w którym to ujęciu tekst źródłowy stanowi dla tłumacza priorytet, co wiąże się z tym, że - zdaniem tego badacza - kontekst kulturowy jest bardzo ważny i należy go zachować w przekładzie. Nie znajdziemy też u Pietrzyk emocjonalnego nastawienia narratora czy udomowionych fraz.

Obie strategie obrane przez tłumaczki mają swoje wady i zalety, obie spełniają też określone funkcje. W przekładzie Kierszys tekst jest zabawny, bliski dziecku i dobrze dostosowany do jego zdolności poznawczych, choć odległy od kontekstu kulturowego opowieści Bemelmansa. Pietrzyk natomiast zachowuje obcość w przekładzie, sytuuje się po stronie zagranicznego kontekstu, co sprawia, że czytelnik ma poczucie obcowania z utworem, który pochodzi z innego kręgu kulturowego. W tłumaczeniu tym zostaje jednak zagubiony rytm wiersza, który zapewnia dynamikę czytania. Autorka wielokrotnie posługuje się rymami niepełnymi, ale także gramatycznymi, które w języku polskim posiadają niski status, co obniża jakość poetycką przekładu.

\section{Zakończenie}

W analizie wierszowanego utworu Bemelmansa starałam się ukazać normy i cele, które, jak sądzę, przyświecały tłumaczkom podczas ich pracy. Podejście Kierszys, adaptacyjne, nieco infantylizujące, nakazuje wykorzystywać inne zabiegi w przekładzie na użytek czytelnika dziecięcego, a inne - w tłumaczeniu dla odbiorcy dorosłego. Podejście bliższe oryginałowi, reprezentowane przez Pietrzyk, opiera się na równych prawach i szansach - nie upraszcza, nie boi się obcości. Różnica między oboma przekładami jest zaś przejawem szerszej tendencji do uniezależniania i eksponowania odbiorcy w poezji dla dzieci.

$\mathrm{Na}$ koniec chciałabym podkreślić jeszcze jeden aspekt wykonania przez obie tłumaczki przekładów Madeline - fakt wprowadzenia twórczości Ludwiga 
Bemelmansa na rynek polski. Choć nadal brak - poza propozycją Pietrzyk rozbudowanych serii przekładowych, co łączy się z niemal całkowitym brakiem polskojęzycznych opracowań naukowych na temat twórczości tego autora ${ }^{23}$, to fakt zainteresowania się cyklem przez duże polskie wydawnictwa (Prószyński i S-ka, Znak) oraz same tłumaczki jest pierwszym krokiem ku zmianie owego stanu rzeczy. Jednocześnie świadomość pewnych niedociągnięć czy mankamentów w istniejących już przekładach, ale zarazem świadomość licznych wyzwań translatorskich, które wiążą się z tłumaczeniem tekstów Bemelmansa, może skłonić kolejnych autorów do ponownego zmierzenia się z oryginałem i do stworzenia przekładu oddającego walory utworu - co być może sprawi, że fenomen pisarza zagości na dłużej także w Polsce.

\section{Bibliografia}

Adamczyk-Garbowska, M. (1988). Polskie tłumaczenia angielskiej literatury dziecięcej. Problemy krytyki przekładu. Wrocław, Warszawa, Kraków: Zakład Narodowy im. Ossolińskich.

Adamczyk-Garbowska, M. (1990). Od tłumaczki. W: A. A. Milne, Fredzia Phi-Phi (M. Adamczyk-Garbowska, tłum., s. 5-7). Lublin: Wydawnictwo Lubelskie.

b.a. (b.d.a). Ludwig Bemelmans. Madeline Wiki. Pobrane z: https://madeline.fandom. com/wiki/Ludwig_Bemelmans.

b.a. (b.d.b). Miss Clavel. Madeline Wiki. Pobrane z: https://madeline.fandom.com/ wiki/Miss_Clavel.

Bader, B. (1976). American picturebooks from Noah's Arc to The Beast Within. New York, NY: Macmillan.

Barańczak, S. (1992a). Mały, lecz maksymalistyczny Manifest translatologiczny albo: Tłumaczenie się z tego, że tłumaczy się wiersze również w celu wytłumaczenia innym tłumaczom, iż dla większości tłumaczeń wierszy nie ma wytłumaczenia. W: Ocalone w tlumaczeniu (s. 13-63). Kraków: Wydawnictwo a5. (wyd. oryg. 1990). Barańczak, S. (1992b). Rice pudding i kaszka manna. O tłumaczeniu poezji dla dzieci. W: Ocalone w tlumaczeniu (s. 67-77). Kraków: Wydawnictwo a5. (wyd. oryg. 1975).

${ }^{23}$ Jedyne polskojęzyczne dotyczące Bemelmansa oraz Madeline opracowania naukowe, do których dotarłam, to hasło Alicji Zbierzchowskiej (2018) na temat tego picturebooka w pierwszym tomie leksykonu Książk obrazkowa oraz rozdział Sylwii Borowik (2017) w pracy Literatura dla dzieci i młodzieży. Tom 5, gdzie utworowi Bemelmansa autorka poświęciła jedno zdanie: „W gronie świadomych swojej siły, otwartych i rezolutnych dziewczęcych bohaterek znajdziemy [...] odważną Madeline, która niczego się nie boi - ani tańczyć na poręczy mostu, ani tygrysa, ani pobytu w szpitalu [...]” (s. 126). 
Barrie, J. M. (1906). Peter Pan in Kensington Gardens. London: Hodder \& Stoughton. Baśń w przekładzie. (2010). Przekładaniec, 22-23(2-1).

Bemelmans, L. (1934). Hansi. New York, NY: Viking.

Bemelmans, L. (1936). The golden basket. New York, NY: Viking.

Bemelmans, L. (1937). The castle number nine. New York, NY: Viking.

Bemelmans, L. (1938). Quito express. New York, NY: Viking.

Bemelmans, L. (1939). Madeline. New York, NY: Simon \& Schuster.

Bemelmans, L. (1956). Madeline's and the bad hat. New York, NY: Viking.

Bemelmans, L. (1959). Madeline's and the Gypsies. New York, NY: Viking.

Bemelmans, L. (1961). Madeline in London. New York, NY: Viking.

Bemelmans, L. (1985). Madeline's Christmas. New York, NY: Viking. (wyd. oryg. 1956).

Bemelmans, L. (1998a). Gwiazdka Madeline (Z. Kierszys, tłum.). Warszawa: Prószyński i S-ka. (wyd. oryg. 1956).

Bemelmans, L. (1998b). Madeline (Z. Kierszys, tłum.). Warszawa: Prószyński i S-ka. (wyd. oryg. 1939).

Bemelmans, L. (2001). Mad about Madeline: The complete tales. New York, NY: Viking. (wyd. oryg. 1939-1961).

Bemelmans, L. (2014). A Madeline treasury: The original stories by Ludwig Bemelmans. New York, NY: Viking. (wyd. oryg. 1939-1961).

Bemelmans, L. (2015a). Madeline. W: Madeline w Paryżu (M. Pietrzyk, tłum., s. 15-59). Kraków: Znak. (wyd. oryg. 1939).

Bemelmans, L. (2015b). Madeline w Paryżu (M. Pietrzyk, tłum.). Kraków: Znak. (wyd. oryg. 1939-1961).

Bemelmans, L. (2015c). Wyspa Boga (lub Początki Madeline). W: Madeline w Paryżu (M. Pietrzyk, tłum., s. 314-317). Kraków: Znak. (wyd. oryg. 1985).

Bemelmans, L., Bemelmans Marciano, J. (1999). Madeline in America and other holiday tales. London: Scholastic.

Bemelmans Marciano, J. (1999). Bemelmans: The life and art of Madeline's creator. New York, NY: Viking.

Bemelmans Marciano, J. (2001). Madeline says Merci. New York, NY: Viking.

Bemelmans Marciano, J. (2005). Madeline loves animals. New York, NY: Viking.

Bemelmans Marciano, J. (2008). Madeline and the cats of Rome. New York, NY: Viking. Bemelmans Marciano, J. (2011). Madeline at the White House. New York, NY: Viking. Bemelmans Marciano, J. (2013). Madeline and the old house in Paris. New York, NY: Viking.

Bilczewski, T. (2010). Komparatystyka i interpretacja. Nowoczesne badania porównawcze wobec translatologii. Kraków: TAiWPN Universitas.

Borodo, M. (2006). Children's literature translation studies? - zarys badań nad literaturą dziecięcą w przekładzie. Przekładaniec, 16(1), 12-23. 
Borowik, S. (2017). Literatura dla dzieci i młodzieży a gender (wybrane przykłady). W: K. Tałuć (red.), Literatura dla dzieci i młodzieży. Tom 5 (s. 120-133). Katowice: Wydawnictwo UŚ.

Bromwich, J. E. (2018, 27 kwietnia). How the author of Madeline created his most famous character. New York Times. Pobrane z: https://www.nytimes.com/2018/04/27/ style/madeleine-author-illustrator.html.

Cackowska, M. (2016). Książka obrazkowa. W: D. Waloszek (red.), Encyklopedia dzieciństwa. Pobrane z: http://encyklopediadziecinstwa.pl/index.php?title=Książka obrazkowa.

Carroll, L. (1865). Alice's adventures in Wonderland. London: Macmillan.

Carroll, L. (1871). Through the Looking Glass, and what Alice found there. London: Macmillan.

Dymel-Trzebiatowska, H. (2014). Translatoryka literatury dziecięcej. Analiza przekładu utworów Astrid Lindgren na język polski. Gdańsk: Wydawnictwo UG.

Dymel-Trzebiatowska, H. (2019). Filozoficzne i translatoryczne wędrówki po Dolinie Muminków. Gdańsk: Wydawnictwo UG.

Ferris, L. (2018, 22 marca). In an old house in Paris, thinking of Madeline. Lingua Franca. Pobrane z: https://www.chronicle.com/blogs/linguafranca/2018/03/22/in-an-old-house-in-paris-thinking-of-madeline/.

FirstMan. (2010, 27 stycznia). Break bread. Urban dictionary. Pobrane z: https://www. urbandictionary.com/define.php?term $=$ Break\%20bread.

Fundacja „ABCXXI - Cała Polska czyta dzieciom”. (2019). Złota lista książek polecanych przez Fundację „ABCXXI - Cała Polska czyta dzieciom” do czytania dzieciom. Pobrane z: http://calapolskaczytadzieciom.pl/ckfinder_pliki/files/Z\%C5\%82ota\%20Lista\%20\%2B\%20lista\%20dla\%20rodzic\%C3\%B3w\%20\%20 -\%2028.08.2019\%281\%29.pdf.

Heyward, A., Maliani, M., London, R., Cooper, S., Kohner, P. (prod.). (1993). Madeline [serial telewizyjny]. Burbank, CA: The Family Channel.

Heyward, A., Maliani, M., London, R., Cooper, S., Kohner, P. (prod.). (1995-2001). The new adventures of Madeline [Nowe Przygody Madeline] [serial telewizyjny]. Burbank, CA: ABC, Disney Channel.

Kellog, C. (2013, 11 października). Is Madeline really 75 years old? Her author talks to NPR. Los Angeles Times. Pobrane z: https://www.latimes.com/books/jacketcopy/ la-et-jc-madeline-75-20131011-story.html.

Klingberg, G. (1986). Children's fiction in the hands of the translators. Lund: Gleerup.

Quindlen, A. (2015). Wstęp. W: L. Bemelmans, Madeline w Paryżu (M. Pietrzyk, tłum., s. 9-12). Kraków: Znak. (wyd. oryg. 2001).

Przekład literatury dziecięcej. (2006). Przekładaniec, 16(1).

Rajewska, E. (2004). Dwie wiktoriańskie chwile w Troi, trzy strategie translatorskie. Alice's Adventures in Wonderland $i$ Through the Looking-Glass Lewisa Carrolla 
w przekładach Macieja Słomczyńskiego, Roberta Stillera i Jolanty Kozak. Poznań: Wydawnictwo PSP.

Rajewska, E. (2015). Twórczość przekładowa kobiet. W: E. Kraskowska, B. Kaniewska (red.), Polskie pisarstwo kobiet $w$ wieku XX. Procesy i gatunki, sytuacje i tematy (s. 269-298). Poznań: WN UAM.

Szymańska, I. (2009). Wymiary obcości w przekładzie dla dzieci. Przypadek Byczka Fernando. Między Oryginałem a Przekładem, 15, 155-172.

Szymańska, I. (2010). Serie translatorskie w polskich przekładach anglojęzycznej literatury dziecięcej. Obraz adresata jako motyw łączący serię. W: K. Hejwowski, A. Szczęsny, U. Topczewska (red.), 50 lat polskiej translatoryki. Materiały z konferencji naukowej zorganizowanej przez Instytut Lingwistyki Stosowanej Uniwersytetu Warszawskiego $w$ Warszawie w dniach 23-25 listopada 2007 r. (s. 513-527). Warszawa: UW.

Szymańska, I. (2014). Przekłady polemiczne w literaturze dziecięcej. Rocznik Przekładoznawczy, 9, 193-208.

Venuti, L. (2009). Strategies of translation. W: M. Baker, G. Saldanha (red.), Routledge encyclopedia of translation studies (s. 240-244). London, New York, NY: Routledge. (wyd. oryg. 1998).

Wieczorkiewicz, A. (2018). Piotruś Pan w Ogrodach Kensingtońskich Jamesa Matthew Barriego. Kontekst - interpretacja - przekład. Lublin: Wydawnictwo KUL.

Zbierzchowska, A. (2018). Madeline. W: M. Cackowska, H. Dymel-Trzebiatowska, J. Szyłak (red.), Ksiązka obrazkowa. Leksykon. Tom 1 (s. 147-153). Poznań: Instytut Kultury Popularnej. 